\title{
DESKRIPSI PENGGUNAAN APLIKASI MICROSOFT TEAMS DALAM PEMBELAJARAN DARING MATA PELAJARAN SEJARAH INDONESIA
}

\author{
Ghalyh Wardhana Putra \\ Universitas Veteran Bangun Nusantara Sukoharjo \\ Ghalyh5684@gmail.com \\ Hajri Taqin Musthofa \\ Universitas Veteran Bangun Nusantara Sukoharjo \\ hajrimusthofa@gmail.com \\ Andriyanto \\ Universitas Veteran Bangun Nusantara Sukoharjo \\ andri_rey@yahoo.co.id
}

\begin{abstract}
The purpose of this study is to describe how the Microsoft Teams application is used in online learning. This study uses a qualitative approach with a descriptive design. The data technique is done by collecting information, interviews, and documentation. The data obtained were then described descriptively. From this method, the research results show that the use of Microsoft Teams in online learning activities is said to be quite effective and efficient. With various features in one application that makes it easier for teachers and students to access, because teachers can deliver materials using various facilities or features provided by the Team, not only in text but also in text. video form. In addition, teachers can also assess the activeness of their students with the chat feature, and can efficiently assign assignments as evaluation materials to see the level of student understanding. In addition, Teams can also be used for video reservations for face-to-face learning via online. This shows that learning using Microsoft Teams is quite efficient in today's online learning process.
\end{abstract}

Keywords: Application, Leaming, Microsoft, Online, Teams

\section{PENDAHULUAN}

Pada akhir tahun 2019, dunia dikejutkan oleh sebuah fakta mengenai munculnya penyakit sangat menular yang menyerang organ pernapasan dan mematikan di daratan Tiongkok. Kasus penyakit menular yang terjadi pertama kali di Wuhan, Provinsi Hubei ini dengan cepat menyebar ke seluruh Tiongkok dan seluruh dunia (WHO, 2020). Sumber penularan diduga berasal dari hewan kelelawar tetapi ini masih belum diketahui dengan pasti, akan tetapi kasus pertama kali dilaporkan berkaitan dengan aktivitas pasar ikan di Wuhan yang juga menjual hewan kelelawar (Beck \& Tobin, 2020; Nishiura et al., 2020). 
Badan Kesehatan Dunia atau WHO mengumumkan secara resmi pada 11 Februari 2020 bahwa penyakit menular ini adalah Corona Virus Disease (COVID-19) yang disebabkan oleh virus Severe Acute Respiratory Syndrome Coronavirus-2 (SARS$\mathrm{CoV}-2$ ). Pada manusia, jenis coronavirus menyebabkan infeksi saluran pernapasan seperti halnya penyakit SARS, MERS yang bersifat mematikan, seperti halnya juga COVID-19. Virus ini dapat ditularkan dari manusia ke manusia, dan telah menyebar luas di Tiongkok serta lebih dari 190 negara dan teritori lainnya (Susilo et al., 2020). Cepatnya penyebaran ini dikarenakan bertepatan dengan waktu libur akhir tahun, perayaan Natal 2019, Tahun Baru 2020, dan menyambut perayaan Imlek, sehingga pergerakan manusia begitu padat antar daerah, maupun antar negara (Putsanra, 2020).

Sejak Januari 2020 kasus infeksi COVID-19 di dunia terus meningkat, pada Maret 2020 lebih dari 190 negara telah mengonfirmasi terjangkit virus ini, dengan jumlah 781.485 kasus (Bramasta, 2020). Pada bulan April jumlah kasus mencapai 3.208.977 kasus (Aida, 2020). Sedangkan pada bulan Mei jumlah kasus mencapai 6.176.242 kasus (G. S. Putri, 2020). Beberapa negara di dunia selain Tiongkok yang mengalami jumlah kasus infeksi terbanyak antara lain Korea Selatan, Jepang, Italia, Spanyol, Amerika Serikat dan beberapa negara lainnya. Di Indonesia kasus COVID-19 pertama kali dilaporkan pada tanggal 2 Maret 2020 dengan jumlah dua kasus. Pada akhir bulan Maret tercatat terdapat 1.528 kasus terkonfirmasi positif terinfeksi (Nugraheny, 2020). Pada bulan April tercatat terdapat 10.118 kasus (Nugraheny, 2020). Sedangkan pada bulan Mei lonjakan kasus masih terus terjadi, yakni mencapai 26.473 kasus (Hakim, 2020) dan seluruh propinsi di wilayah Indonesia telah melaporkan adanya kasus di setiap daerah.

Dalam situasi saat ini, COVID-19 bukanlah wabah yang dapat diabaikan. Di Indonesia penyebaran virus ini telah melalui transmisi lokal secara signifikan atau penularan telah terjadi di dalam daerah tertentu. Dalam rangka mengantisipasi dan mengurangi penyebaran virus serta kasus infeksi di Indonesia, pemerintah telah mengambil salah satu kebijakan yakni pembatasan aktivitas di ruang publik secara langsung. Seperti pembatasan aktivitas di luar rumah, kegiatan sekolah dirumahkan, bekerja dari rumah (work from home), serta 
DESKRIPSI PENGGUNAAN APLIKASI MICROSOFT TEAMS DALAM PEMBELAJARAN

DARING MATA PELAJARAN SEJARAH INDONESIA

(Ghalyh Wardhana Putra, Hajri Taqin Musthofa, Andriyanto)

kegiatan ibadah dilaksanakan di rumah. Kebijakan ini merupakan bentuk implementasi dari kekarantinaan kesehatan. Dengan kebijakan ini diharapkan dapat menekan jumlah penyebaran virus dan menekan penambahan kasus infeksi COVID-19 (Yunus \& Rezki, 2020).

Pandemi COVID-19 membawa dampak sangat besar bagi aspek kehidupan masyarakat. Dampak tersebut terjadi di berbagai bidang seperti sosial, ekonomi, pariwisata, dan tak luput juga bidang pendidikan. Pemerintah mengeluarkan Surat Edaran (SE) pada tanggal 18 Maret 2020 menyatakan bahwa segala kegiatan di dalam dan di luar ruangan di semua sektor akan ditunda sementara waktu, terutama bidang pendidikan. Kementerian Pendidikan dan Kebudayaan Republik Indonesia kemudian menindaklanjuti dengan mengeluarkan Surat Edaran Nomor 4 Tahun 2020 tentang Pelaksanaan Kebijakan Pendidikan dalam Masa Darurat Penyebaran COVID-19. Pembelajaran di sekolah kemudian dilaksanakan secara daring atau pembelajaran jarak jauh. Belajar di rumah dapat difokuskan pada pendidikan kecakapan hidup antara lain mengenai pandemi COVID-19 (Dewi, 2020).

Akibatnya hal tersebut menjadikan tantangan bagi seluruh elemen pendidikan baik sekolah maupun guru untuk menentukan strategi dan media pembelajaran yang tepat untuk pengembangan sistem pembelajaran daring tersebut sehingga dapat mencapai tujuan pembelajaran sebagaimana pembelajaran secara tatap muka langsung. Pembelajaran merupakan proses kompleks dalam diri peserta didik dan terkait dengan berbagai aspek dalam diri maupun luar dirinya. Guru sebagai pemberi fasilitas belajar dituntut memiliki kemampuan dalam memilih dan menerapkan strategi pembelajaran. Dengan kemampuan tersebut guru dapat melaksanakan fungsi pemberi fasilitas dengan baik sehingga peserta didik dapat melakukan aktivitas belajar secara efektif (Kusumaningsih, 2011).

Melihat berbagai fakta tersebut, maka penerapan metode online learning ( $e$ learning) menjadi suatu pilihan terbaik bagi dunia pendidikan. Berbagai institusi pendidikan saat ini mulai memanfaatkan teknologi dan menerapkan sistem pembelajaran daring untuk menunjang aktivitas pembelajaran.

Pembelajaran daring adalah pembelajaran yang mampu mempertemukan mahasiswa dan dosen untuk melaksanakan interaksi pembelajaran dengan bantuan 
internet (Kuntarto, 2017). Penggunaan teknologi dalam pendidikan merupakan alternatif untuk meningkatkan kualitas dan kuantitas hasil dan proses dalam pembelajaran. Maka guru dan peserta didik dituntut aktif untuk menggunakan teknologi pendidikan dalam proses pembelajaran.

Pembelajaran secara daring merupakan cara baru dalam proses belajar mengajar yang memanfaatkan perangkat elektronik khususnya internet dalam penyampaian belajar. Pembelajaran daring, sepenuhnya bergantung pada akses jaringan internet (Ezalia et al., 2020). Pembelajaran daring merupakan bentuk penyampaian pembelajaran konvensional yang dituangkan pada format digital melalui internet. Pembelajaran daring, dianggap menjadi satu-satunya media penyampai materi antara guru dan siswa, dalam masa darurat pandemi (Imania \& Bariah, 2019).

Pembelajaran daring dapat menggunakan video conference (webinar Zoom, Webex), Microsoft Teams, Microsoft Form, Whatsapp maupun aplikasi lainnya. Kemunculan media pembelajaran daring ini sudah lama ada. Akibat pandemi Covid-19 banyak sekolah beralih ke pembelajaran jarak jauh dan penggunaan berbagai media pembelajaran daring ini mulai merebak di Indonesia. Salah satunya adalah SMK Muhammadiyah 1 Sukoharjo yang saat ini juga menggunakan sistem pembelajaran daring. Di SMK Muhammadiyah 1 Sukoharjo media yang digunakan untuk pembelajaran daring adalah Microsoft Teams dan Whatsapp. Dalam artikel ini akan membahas salah satu media yang digunakan yaitu Microsoft Teams. Berbagai latar belakang tersebut memunculkan rumusan masalah: Bagaimana penggunaan aplikasi Microsoft Teams dalam pembelajaran daring mata pelajaran Sejarah Indonesia ?

\section{METODE}

Penelitian ini dibuat berdasarkan pengalaman lapangan di SMK Muhammadiyah 1 Sukoharjo yang menerapkan aplikasi Microsoft Teams dalam pembelajaran daring mata pelajaran Sejarah Indonesia. Penelitian ini menggunakan pendekatan kualitatif dengan desain deskriptif, untuk memberikan gambaran tentang pemanfaatan aplikasi Microsoft Teams dalam pembelajaran daring mata pelajaran Sejarah Indonesia di SMK Muhammadiyah 1 Sukoharjo. 
DESKRIPSI PENGGUNAAN APLIKASI MICROSOFT TEAMS DALAM PEMBELAJARAN

DARING MATA PELAJARAN SEJARAH INDONESIA

(Ghalyh Wardhana Putra, Hajri Taqin Musthofa, Andriyanto)

Teknik pengumpulan data dilakukan dengan pengumpulan berupa informasi, wawancara, dan dokumentasi. Data yang diperoleh tersebut, kemudian dijabarkan secara deskriptif.

\section{HASIL DAN PEMBAHASAN}

Microsoft Teams for Education merupakan salah satu media pembelajaran daring yang dirancang di dalam microsoft office 365. Office 365 merupakan kolaborasi berbagai perangkat lunak yaitu Microsoft Office, Microsoft Share Point Online, Microsoft Exchange Online dan Microsoft Lync Online yang selalu terhubung dengan layanan komputasi awan atau Cloud. Komputasi berbasis awan sendiri adalah layanan komputer yang berbasis Cloud atau berbasis awan yang artinya merupakan gabungan pemanfaatan teknologi komputer dalam suatu jaringan dengan pengembangan berbasis internet (Cloud) yang mempunyai fungsi untuk menjalankan program atau aplikasi melalui komputer-komputer yang terkoneksi pada waktu yang sama secara bersama, tetapi tak semua yang terkonekasi melalui internet menggunakan komputasi awan. Teknologi komputer berbasis sistem Cloud ini merupakan sebuah teknologi yang menjadikan internet sebagai pusat server untuk mengelola data dan juga aplikasi pengguna (Sudarmoyo, 2018).

Teknologi ini mengizinkan para pengguna untuk menjalankan program tanpa instalasi dan mengizinkan pengguna utuk mengakses data pribadi mereka melalui komputer dengan akses internet. Dalam office 365 ada beberapa program berbasis awan, antara lain : Outlook, One Drive,Word, Exel,Power Point, One Note, Share Point, Teams, Classnote, Sway dan Form.

Office 365 adalah layanan langganan berbasis Cloud dengan peralatan terbaik yang memungkinkan semua orang bekerja dengan cara modern. Dengan menggabungkan aplikasi terbaik di kelasnya seperti Excel dan Outlook dengan layanan Cloud canggih seperti OneDrive dan Microsoft Teams. Office 365 memungkinkan semua orang menghasilkan dan berbagi banyak hal di mana saja di semua perangkat. Gambar dibawah ini menunjukan fitur aplikasi yang tersedia dalam Microsoft Office 365. 


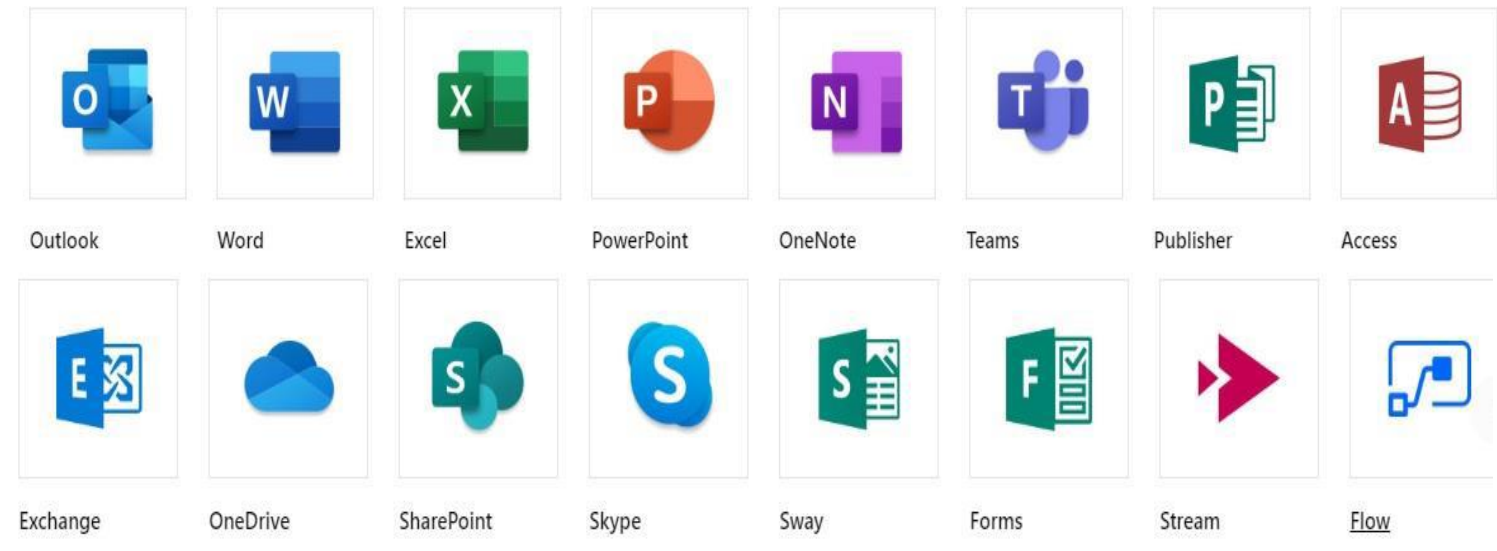

(Gambar 1. Fitur aplikasi Microsoft office 365)

Dalam fitur Microsoft Office 365 yang digunakan di SMK Muhammadiyah 1 Sukoharjo salah satu yang utama adalah Teams. Teams adalah aplikasi hubungan kolaborasi tim di Office 365 yang mengintegrasikan semua orang, konten, dan alat yang dibutuhkan tim agar terlibat dalam satu tempat yang sama.

Office 365 memiliki Microsoft Teams sebagai digital hub yang menghubungkan berbagai layanan Office 365 dalam satu ruang kerja memungkinkan guru dan siswa untuk mencapai hal lebih, karena mereka dapat berinteraksi dan berkomunikasi dengan mudah. Hal ini didukung dengan adanya fitur obrolan yang disematkan di dalam Microsoft Teams yang memungkinkan siswa melakukan konsultasi secara personal atau pun kelompok, ataupun sebaliknya, pendidik membimbing seluruh siswa langsung dari percakapan di dalam kelas virtual atau pun langsung secara personal kepada setiap siswa.

Agar lebih produktif, sebuah tim kerja perlu didukung oleh sistem yang efektif dan efisien. Di dalam sistem ini, para anggota tim dapat membangun komunikasi secara intens untuk menciptakan kolaborasi ideal. Berperan sebagai pusat kerja tim di Microsoft Office 365. Microsoft Teams hadir dengan dukungan sejumlah fitur unggulan yang memfasilitasi seluruh anggota tim. Bagaimana Microsoft Teams dapat membantu meningkatkan kinerja dalam berkomunikasi, berbagi dokumen, mengadakan pertemuan bersama, dan itu semua dilakukan secara daring (Panduan Penggunaan Aplikasi Microsoft Teams MICROSOFT TEAMS PLATFORM, n.d.). 
DESKRIPSI PENGGUNAAN APLIKASI MICROSOFT TEAMS DALAM PEMBELAJARAN

DARING MATA PELAJARAN SEJARAH INDONESIA

(Ghalyh Wardhana Putra, Hajri Taqin Musthofa, Andriyanto)

Microsoft Teams adalah hub digital yang menyatukan percakapan, konten, penugasan, dan aplikasi di satu tempat, memungkinkan guru menciptakan lingkungan belajar yang dinamis. Microsoft bertujuan untuk menawarkan pengalaman belajar jarak jauh sebagai pribadi, menarik dan terhubung secara sosial seperti belajar di kelas. Microsoft Teams memungkinkan siswa dan guru dapat tetap berkomunikasi dan saling membantu menggunakan percakapan, dan dapat merasa seperti mereka bertemu langsung menggunakan pertemuan langsung. Guru dapat melacak kemajuan siswa dalam pekerjaan sehari-hari mereka menggunakan tugas. Sama seperti di ruang kelas, guru dapat menggunakan aplikasi dan fungsi tim untuk mendukung cara mereka bekerja terbaik (Education \& Vol, n.d.).

Teams menangani kebutuhan yang unik dari kelompok yang berbeda dan memungkinkan mereka bekerja sama secara mudah dan menyelesaikan pekerjaan:

1. Mengelola proyek, tugas, dan konten dengan menggunakan aplikasi yang digunakan setiap hari, dan semua tersedia dalam satu ruang kerja yang dapat disesuaikan.

2. Terus mengikuti informasi dan pembaruan real-time yang dibagikan dalam percakapan tim tetap, obrolan pribadi (semuanya dapat dimodifikasi, jika diperlukan), rapat tim, dan saluran lain.

3. Mendukung kolaborasi yang beragam dan pengalaman yang mudah dengan aplikasi terintegrasi dari Office 365 seperti Word, Excel, PowerPoint, dan Buku Catatan Kelas OneNote (Pradja et al., 2019). 
Berikut adalah gambar tampilan Microsoft Teams:

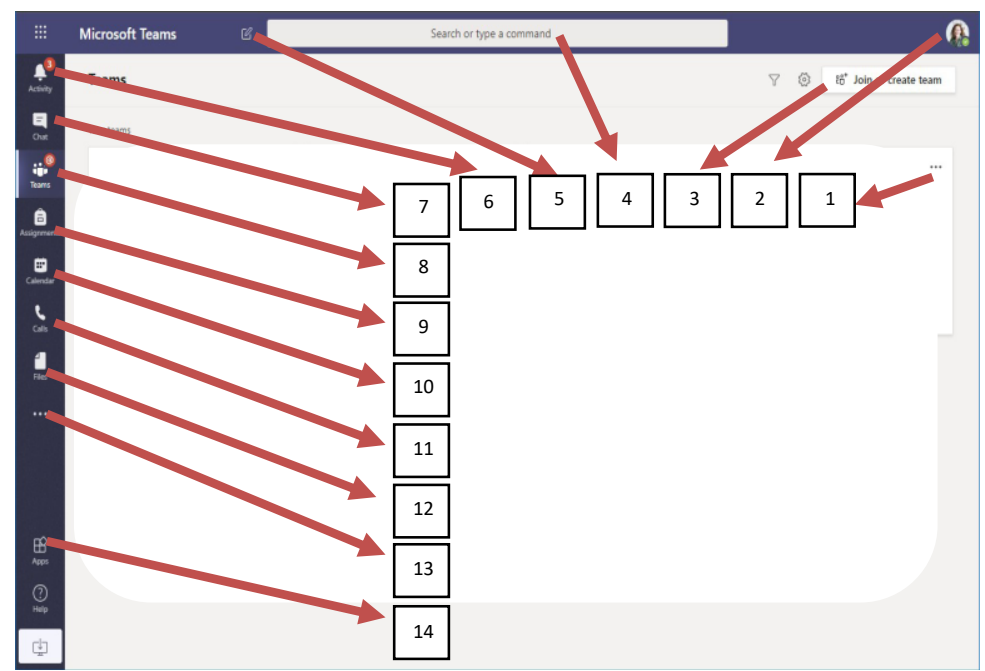

(Gambar 2. Tampilan aplikasi Microsoft Teams)

Keterangan:

1. Mengelola Tim, sebagai penambah atau memindahhkan anggota tim, membuat channel atau melihat daftar tim yang ada.

2. Profile settings, untuk merubah setting/pengaturan pada aplikasi, merubah gambar atau download aplikasi mobile.

3. Bergabung atau Membuat Tim, untuk bergabung terhadap tim yang sudah dibuat sebelumnya atau membuat grup tim baru.

4. Pencarian, untuk mencari item aplikasi, orang, sebagai menu akses cepat dan menjalankan aplikasi.

5. Chat, untuk menulis pesan antar individu, individu lintas tim, maupun individu se-organisasi.

6. Activity, berguna untuk mengetahui aktivitas secara realtime yang dilakukan.

7. Chat, berguna untuk memulai percakapan dan menyimpan percakapan.

8. Teams, berguna untuk membuat group.

9. Assignment, berguna untuk memberikan penugasan yang bersifat seperti kelas.

10. Calendar, berguna untuk menyusun jadwal kegiatan sesuai kalender.

11. Calls, berguna untuk memulai conference call. 
DESKRIPSI PENGGUNAAN APLIKASI MICROSOFT TEAMS DALAM PEMBELAJARAN DARING MATA PELAJARAN SEJARAH INDONESIA

(Ghalyh Wardhana Putra, Hajri Taqin Musthofa, Andriyanto)

12. Files, berguna untuk melihat file yang di share serta menambahkan cloud storage.

13. Tambahan aplikasi, berguna untuk menambahkan aplikasi.

14. Aplikasi, berguna untuk menambahkan aplikasi yang telah terintegrasi dengan Microsoft Teams dari cloud Microsoft (Zoom et al., n.d.).

Di dalam Microsoft Teams guru dapat melaksanakan pembelajaran di mulai dari mengabsen siswa, memberikan dan menyampaikan materi yang dapat menggunakan powerpoint, word, bahkan video dari youtube. Guru dapat memberikan tugas dan ulangan harian kepada siswa melalui fitur form di dalam Microsoft Teams. Seperti pada gambar di bawah ini.

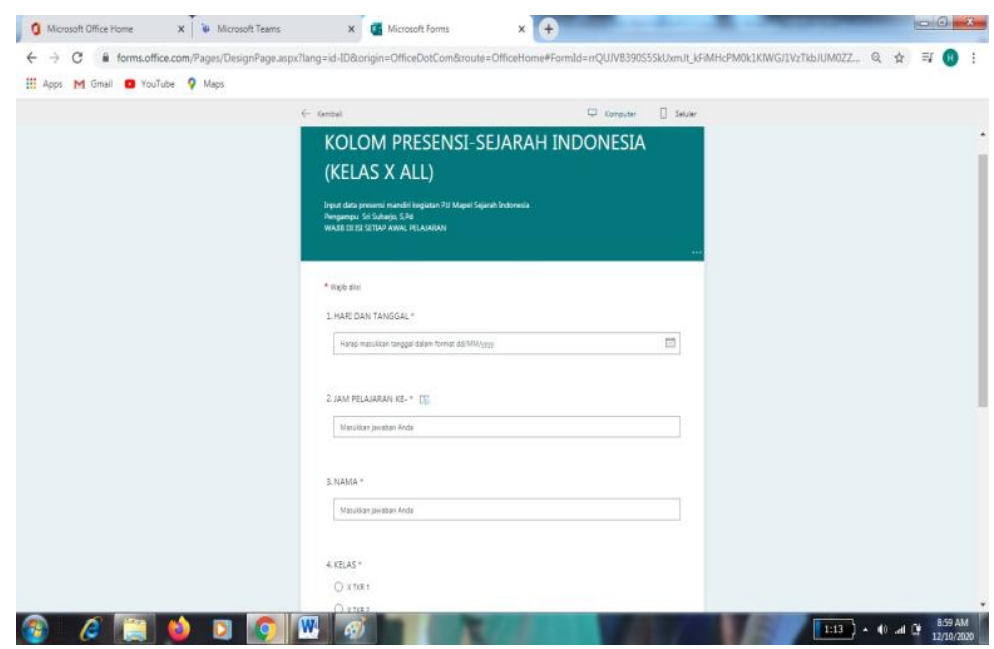

(Gambar 3. Absen di dalam Teams)

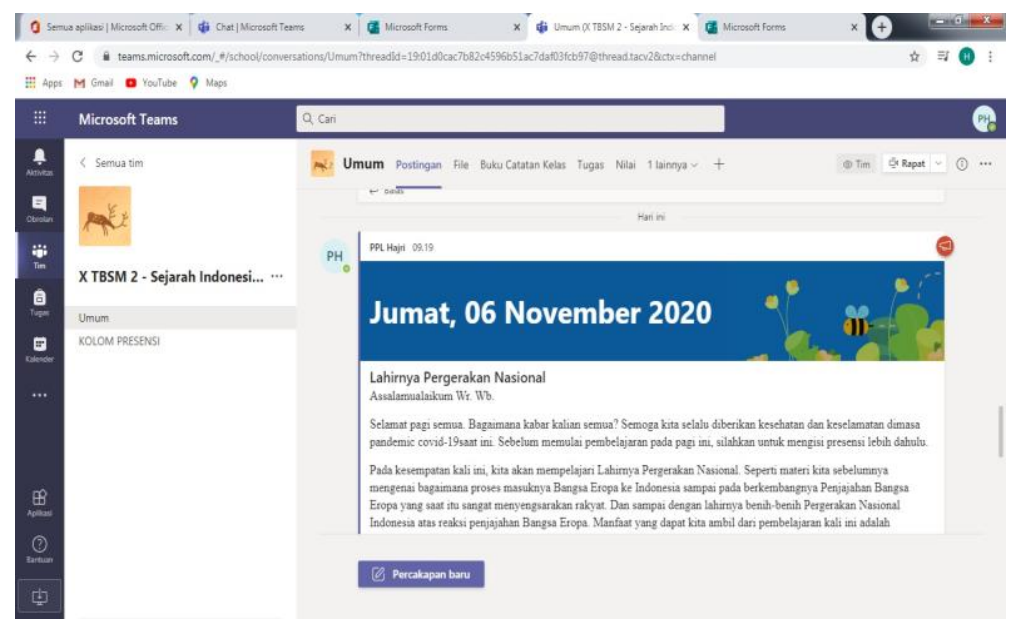

(Gambar 4. Pemberian materi di dalam Teams) 


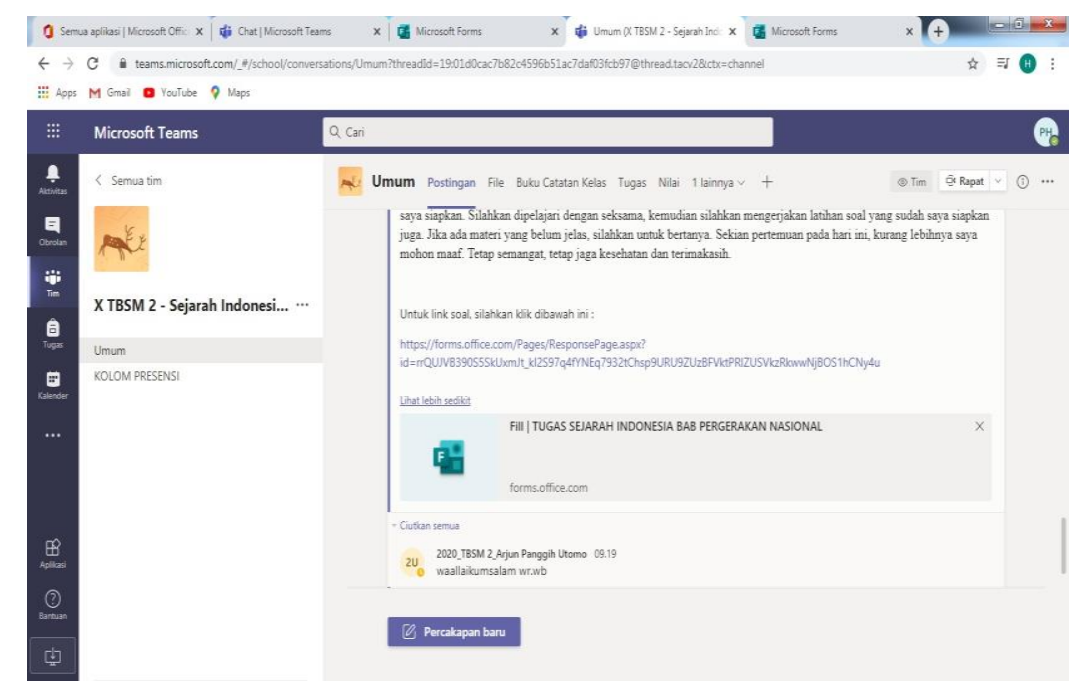

(Gambar 5. Pemberian tugas di dalam Teams)

Dalam satu aplikasi Microsoft Office 365 pembelajaran dapat berlangsung dengan fitur-fitur penunjang yang dapat mempermudah guru dan siswa dalam proses pembelajaran. Selain itu, siswa dapat membuat tim untuk diskusi kelompok, proyek, aktivitas berbeda (yang diperlukan) dan mengundang orang lain dalam sekolah untuk bergabung sebagai anggota tim. Microsoft Teams juga dapat dibuat berdasarkan grup Office 365 yang sudah ada, dan segala perubahan pada grup Office 365 secara otomatis akan disinkronnisasi ke dalam Teams. Sistem tersebut menyederhanakan proses pengundangan dan pengelolaan anggota tim, dan menyimpan file grup di Microsoft Teams. Selain itu Microsoft Teams juga dapat digunakan untuk video conference untuk pembelajaran tatap muka melalui daring.

Sebagai contoh, kelas individual dapat lebih lanjut dikelola menjadi saluran (channel) yang berisi tab untuk percakapan, file, catatan, dan sebagainya. Saluran dapat dibuat berdasarkan kebutuhan kelas yang beragam, misalnya, berdasarkan unit, subjek, atau grup berbasis proyek. Tab memungkinkan kelas mengunggah, meninjau, mengedit file, catatan, dan konten yang dapat disesuaikan (seperti dokumen, lembar kerja, presentasi, video, tautan eksternal, aplikasi lain, dan sebagainya). Konten ini dapat diakses dengan mudah oleh semua mahasiswa didalam kelas (Pradja et al., 2019). 
DESKRIPSI PENGGUNAAN APLIKASI MICROSOFT TEAMS DALAM PEMBELAJARAN

DARING MATA PELAJARAN SEJARAH INDONESIA

(Ghalyh Wardhana Putra, Hajri Taqin Musthofa, Andriyanto)

Keuntungan menggunakan Teams yaitu Mendapatkan keuntungan produktivitas dan komunikasi yang semakin diperkaya, fokus yang lebih baik pada pekerjaan dan sekolah, transparansi meningkat, memudahkan kerjasama yang baik pada tempat kerja/sekolah digital, kemudahan masuknya anggota tim baru dapat lebih cepat meningkatkan kecepatannya (Pradja et al., 2019).

Selain itu juga terdapat kendala dalam penggunaan Microsoft Teams yaitu siswa masih cukup pasif dalam pelaksaan pembelajaran daring. Tetapi, dari kendala tersebut masih dapat diatasi oleh guru. Hal tersebut yang membuat guru juga menggunakan aplikasi whatsapp untuk mengingatkan siswa saat akan dilaksanakan pembelajaran daring di Microsoft Teams.

\section{SIMPULAN}

Dengan menggunakan Microsoft Teams dalam kegiatan pembelajaran daring mata pelajaran Sejarah Indonesia dapat dikatakan cukup efektif dan efisien. Dengan bermacam-macam fitur dalam satu aplikasi membuat banyak kemudahan bagi guru dan siswa dalam penggunaannya, karena guru dapat menyampaikan bahan ajar dengan menggunakan berbagai kemudahan atau fitur yang telah disediakan oleh Microsoft Teams, tidak hanya berupa teks melainkan bisa berupa video. Selain itu, guru dapat juga memantau keaktifan siswanya dengan fitur chat, serta dapat dengan efisien dalam memberikan tugas sebagai bahan evaluasi untuk mengetahui tingkat pemahaman siswa. Selain itu Microsoft Teams juga dapat digunakan untuk video conference untuk pembelajaran tatap muka melalui daring. Hal ini menunjukkan bahwa pembelajaran menggunakan Microsoft Teams cukup efisien dalam proses pembelajaran daring saat ini.

\section{DAFTAR PUSTAKA}

Aida, N. R. (2020). Update Virus Corona Dunia 30 April: 3,2 Juta Orang Terinfeksi, 997.181 Sembuh, 227.628

Meninggal. Kompas. https://www.kompas.com/tren/read/2020/ 04/30/080532665/update-virus-corona-d unia-30-april-32-juta-orangterinfeksi-997181-sembuh 
Beck, M., \& Tobin, D. (2020). The 2019/2020 Novel Corona Virus Outbreak: An International Health Management Perspective. The Open Public Health Journal, 13(1), 52-54. https://doi.org/10.2174/1874944502013010052

Bramasta, D. B. (2020). Update Virus Corona di Dunia 31 Maret: 781.485 Kasus, 164.726 Sembuh, 37.578 Meninggal. Kompas. https:/www.kompas.com/tren/read/2020/03/31/073100765/update- viruscorona-di-dunia-31-maret-781485-kasus-164726-sembuh-37578

Dewi, W. A. F. (2020). Dampak COVID-19 terhadap Implementasi Pembelajaran Daring di Sekolah Dasar. EDUKATIF: Jurnal Ilmu Pendidikan, 2(1), 55-61. https://doi.org/https://doi.org/10.31004/edukatif.v2i1.89

Education, M., \& Vol, A. (n.d.). MICROSOFT TEAMS FOR EDUCATION SEBAGAI MEDIA PEMBELAJARAN. 02(01), 30-35.

Hakim, R. N. (2020). Update: Sebaran 700 Kasus Baru Covid-19 pada 31 Mei. Kompasiana.Com. https://nasional.kompas.com/read/2020/05/31/16302061/update-sebaran700-kasus- baru-covid-19-pada-31-mei

Imania, K. A., \& Bariah, S. K. (2019). Rancangan Pengembangan Instrumen Penilaian Pembelajaran Berbasis Daring. Jurnal Petik, 5(1), 31-47. https://doi.org/10.31980/jpetik.v5i1.445

Kuntarto, E. (2017). Keefektifan Model Pembelajaran Daring Dalam Perkuliahan Bahasa Indonesia di Perguruan tinggi. Journal Indonesian Language Education and Literature, 3(1), 53-65. http://www.syekhnurjati.ac.id/jurnal/index.php/jeill/\%0APEMBELAJARA $\mathrm{N}$

Kusumaningsih, D., \& Press, U. B. (2011). Strategi pembelajaran bahasa Indonesia.

Nugraheny, D. E. (2020). Update per 31 Maret: 1.528 Kasus Covid-19, Masyarakat Diajak Saling Beri Edukasi.

Kompas.https://nasional.kompas.com/read/2020/04/01/06293531/updateper-31-maret-1528- kasus-covid-19-masyarakat-diajak-saling-beri

Panduan Penggunaan Aplikasi Microsoft Teams MICROSOFT TEAMS PLATFORM. (n.d.).

Pradja, B. P., Baist, A., \& Tangerang, U. M. (2019). ANALISIS KUALITATIF PENGGUNAAN MICROSOFT TEAMS DALAM. 415-420. 
DESKRIPSI PENGGUNAAN APLIKASI MICROSOFT TEAMS DALAM PEMBELAJARAN DARING MATA PELAJARAN SEJARAH INDONESIA

(Ghalyh Wardhana Putra, Hajri Taqin Musthofa, Andriyanto)

Sudarmoyo. (2018). Pemanfaatan aplikasi sway untuk media pembelajaran. Jurnal Pendidikan Dan Pembelajaran, Vol 3 No 4 (2018, 3(4).

Susilo, A., Rumende, C. M., Pitoyo, C. W., Santoso, W. D., Yulianti, M., Herikurniawan, H., Sinto, R., Singh, G., Nainggolan, L., Nelwan, E. J., Chen, L. K., Widhani, A., Wijaya, E., Wicaksana, B., Maksum, M., Annisa, F., Jasirwan, C. O. M., \& Yunihastuti, E. (2020). Coronavirus Disease 2019: Tinjauan Literatur Terkini. Jurnal Penyakit Dalam Indonesia, 7(1), 45-67. https://doi.org/10.7454/jpdi.v7i1.415

Yunus, N. R., \& Rezki, A. (2020). Kebijakan Pemberlakuan Lock Down Sebagai Antisipasi Penyebaran Corona Virus Covid-19. SALAM: Jurnal Sosial Dan Budaya Syar-I, 7(3). https://doi.org/10.15408/sjsbs.v7i3.15083

Zoom, P. A., Aplikasi, P., \& Teams, M. (n.d.). Panduan panduan singkat singkat. 